\title{
УЛЬТРАСТРУКТУРНІ ОСОБЛИВОСТІ ПАРЕНХІМИ ТА СУДИН ПЕЧІНКИ ТА НИРОК ЩУРА У РІЗНІ ПЕРІОДИ ЕКСПЕРИМЕНТАЛЬНОГО РОЗЛИТОГО ПЕРИТОНІТУ
}

\author{
ДВНЗ «Тернопільський державний медичний університетімені І. Я. Горбачевського МОЗ України»
}

РЕЗЮМЕ. У роботі представлені результати морфологічних проявів структурно перебудови паренхіми та кровоносних судин нирок і печінки щура у динаміці розвитку розлитого калового перитоніту на ультраструктурному рівні. Доведено однотипність виникнення та характерну послідовність розвитку ультраструктурних змін в судинах печінки і нирок, що є наслідком безпосередніх гемодинамічних розладів, характерних для різних стадій перитоніту. Виявлено особливості структурно перебудови судинного русла нирок та печінки щура, які виникають внаслідок токсичних впливів продуктів обміну, що поступають в кровоносне русло із черевно порожнини. Відмічено більш інтенсивну динаміку морфологічних змін клітин печінки та судинного русла ніж нирок як безпосередню реакцію на токсичні впливи з боку уражено очеревини.

КЛЮЧОВІ СЛОВА: перитоніт, судини, нирки, печінка.

Вступ. Проблема гнійно-септичних захворювань черевно порожнини з кожним роком стає все актуальнішою, про що свідчать численні дослідження, що проводяться у даному напрямку $[1,2]$.

Щодо гострого розлитого перитоніту, то він на даний час продовжує посідати одне із вагомих місць в структурі гостро хірургічно патологі органів черевно порожнини. Гострий гнійний розлитий перитоніт, який супроводжується тотальним пошкодженням всіх основних ланок гомеостазу, пригнічує функці детоксикаційних органів і систем, що, в свою чергу, стає ще однією з причин зростання в організмі концентраці ендотоксинів, з безпосередньою прямою токсичною дією [3].

Відомо, що одним із основних органів детоксикаці і важливим бар'єром на шляху транслокаці різних токсинів, що йдуть із черевно порожнини, 6 печінка, зростання ж кількості токсичних речовин при прогресуванні гострого гнійного розлитого перитоніту призводить до значного зниження антитоксично і бар'єрно функцій печінки, викликаючи

Функціональні і морфологічні зміни, які можна зафіксувати на ультрамікроскопічному рівні [4].

Порушення функці нирок при даній патологі $\epsilon$ одним з основних проявів поліорганно недостатності та відображає тяжкість патологічного процессу.

Мета дослідження: встановити морфологічні прояви структурно перебудови паренхіми та кровоносних судин нирок і печінки щура у динаміці розлитого калового перитоніту на ультраструктурному рівні.

Матеріали та методи дослідження. Експериментальне дослідження проведено на 33 білих щурах-самцях з масою тіла 180-200 г., 9 тварин з яких складали інтактну контрольну групу. 24 тваринам моделювали гострий розлитий перитоніт шляхом внутрішньоочеревинного введення 10 \% калово суміші. Забій тварин здійснювали шляхом введення великих доз концентрованого тіопенталу натрію з наступною х декапітацією через 6, 12, 24 і 36 годин від початку експеримент, після чого проводили забір біологічного матеріалу для подальшого дослідження.

Забір матеріалу для електронномікроскопічного вивчення структурних компонентів тканин печінки і нирок проводили згідно з загальноприйнятими правилами. Для досліджень забирали маленькі шматочки із різних відділів печінки та нирок. Матеріал фіксували у 2,5 \% розчині глютаральдегіду з активною реакцією середовища pH 7,3-7,4, приготовленому на фосфатному буфері Міллоніга. Фіксований матеріал через 50-60 хвилин переносили у буферний розчин і промивали протягом 20-30 хвилин. Постфіксацію здійснювали $1 \%$ розчином чотириокису осмію на буфері Міллоніга протягом 60 хвилин, після чого проводили його дегідратацію в спиртах і ацетоні та заливали в суміш епоксидних смол і аралдиту.

Ультратонкі зрізи, виготовлені на ультрамікротомах УМПТ-7, забарвлювали 1 \% водним розчином уранілацетату, контрастували цитратом свинцю згідно з методом Рейнольдса та вивчали в електронному мікроскопі ПЕМ - 125К.

Результати й обговорення. Ультраструктурне дослідження паренхіматозних елементів і гемомікроциркуляторного русла печінки та нирок дозволило виявити певну динаміку х структурно реорганізаці як відповіді на гемодинамічні зрушення. В ранні терміни (6 годин від початку експерименту) ендотеліоцити капілярів як печінки, так і ниркових клубочків реагували посиленням своє функціонально активності. Це проявлялося наростанням інтенсивності піноцитозу, внаслідок чого піноцитозні везикули займали положення біля цитомембран, а також деяким збільшенням кількості мітохондрій з ущільненим матриксом і чіткими кристами. Зі сторони гепатоцитів і епітелію ниркових канальців у цей термін намічалися зміни дистрофічного характеру, зокрема як прояви гідропічно дистрофі (рис. 1). Цитоплазма таких клітин 
Оеляди літератури, ориаінальні дослідження, поеляд на проблему

просвітлювалася, відмічалося вогнищеве руйнування крист мітохондрій, фрагментація гранулярного цитоплазматичного ретикулуму, ядра клітин ущільнювалися, а гетерохроматин конденсувася, утворюючи невеликі гранули.

В просвіті капілярів нирок і синусо дів печінки нерідко можна було виявити скупчення еритроцитів. Дванадцятигодинний термін спостереження характеризувався подальшим прогресуванням попередньо виявлених змін. Щодо капілярів клу-

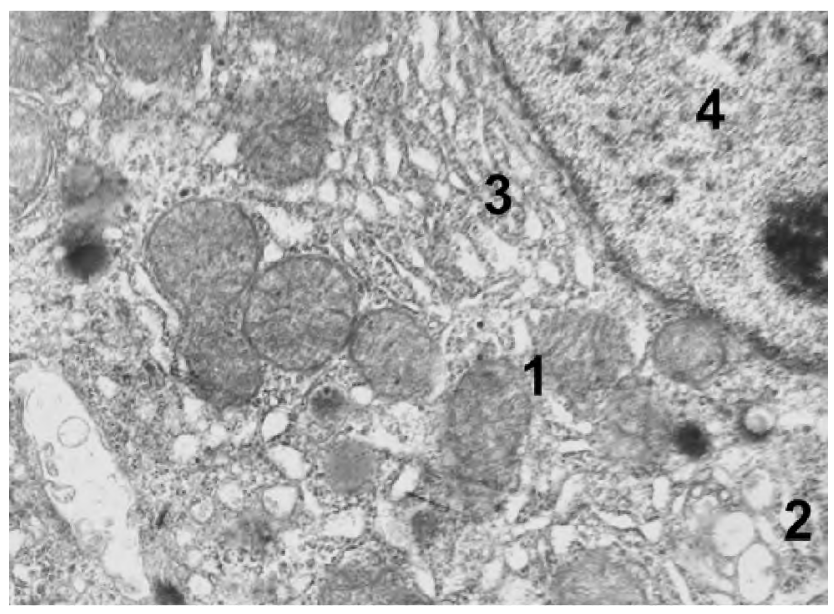

Рис. 1. Гепатоцит щура через 6 годин від початку моделювання гострого розлитого гнійного перитоніту. Фото з електронограми. Збільшення $\times$ 36000. Мітохондрі із частково зруйнованими кристами (1), вакуолізація цитоплазми (2), фрагментація ендоплазматичного ретикулуму (3), конденсація хроматину у ядрі (4).

Звуження просвіту мікросудин призводило до погіршення мікроциркуляці i як наслідок - до поглиблення дистрофічних і розвитку деструктивних змін в паренхіматозних клітинах. Тому прогресування змін дистрофічного характеру спостерігалося і в епітеліоцитах ниркових канальців. На поверхні х цитолеми зменшувалася кількість мікроворсинок. В протоплазмі спостерігалося руйнування крист мітохондрій і лізис самих органел з вакуолізацією протоплазми. Ядра нерідко виглядали пікнотичними. Конденсований у часточки хроматин локалізувався переважно біля каріолеми (рис. 3). Стази в розширених синусо дах досить часто зустрічалися і при ультраструктурному дослідженні печінки експерименнтальних тварин. Нерідко еритроцити формували «монетні стовпчики», або утворювали мікротромби. Ендотелій таких синусо дів виглядав набряклим з просвітленою цитоплазмою. В гепатоцитах відмічалися виражені дистрофічні і деструктивні явища, які полягали в деструкці крист мітохондрій і Фрагментаці самих органел з утворенням на $\mathrm{x}$ місці різно величини вакуолей, а також розширенням цистерн ендоплазматичного ретикулуму і збільшенням кількості лізосом (рис. 4). бочків ниркових тілець, то х просвіт відчутно звужувався, нерідко ставав щілиноподібним (рис. 2). При цьому протоплазма ендотеліоцитів ущільнювалася, а кількість фенестр і мікровиростів у них помітно зростала. Контакти між клітинами ендотелію були досить щільними. При цьому розширювалися і міжклітинні гомогенні поля. Базальні мембрани місцями виглядали нечіткими, погано контурованими. Цитоплазма подоцитів, навпаки, виглядала просвітленою із зменшеною кількістю органел.

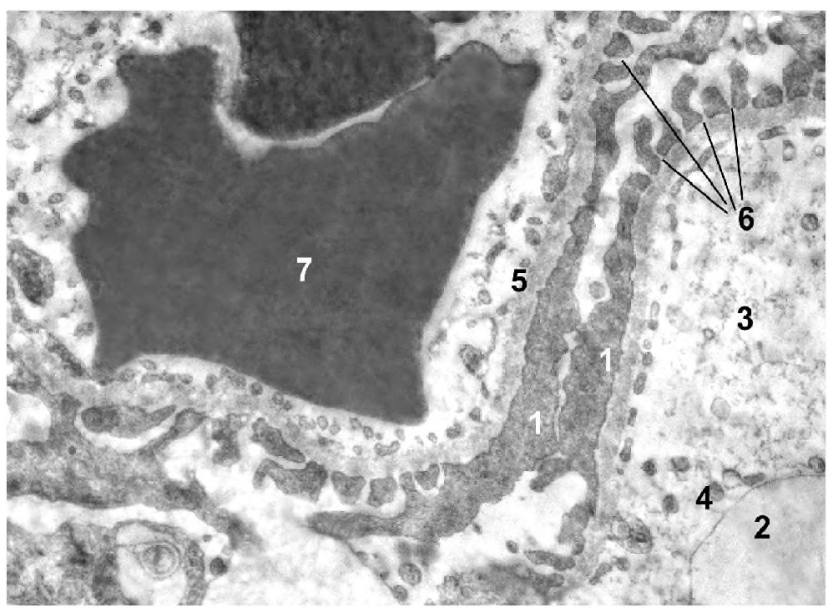

Рис. 2. Ультраструктура елементів ниркового клубочка щура через 12 годин від початку моделювання гострого розлитого гнійного перитоніту. Фото з електронограми. Збільшення × 16000. Клітини ендотелію капіляра (1), ядро подоцита (2), протоплазма подоцита (3), органели з біляядерною локалізацією (4), базальна мембрана (5), фенестри в клітинах ендотелію (6), гомогенне міжклітинне поле (7).

Терміни спостереження в 24-36 годин і пізніше характеризувалися максимальним зниженням пропускно здатності гемомікроциркуляторного русла з переходом до виснаження його регулюючих можливостей з наступним паралітичним розширенням мікросудин. Це проявлялося численними стазами, мікротромбозами. В термінальній стаді виражені деструктивні зміни спостерігалися не тільки в паренхіматозних клітинах, але й у ендотелі капілярів. Базальні мембрани капілярів ниркових тілець погано контурувалися, були нерідко розволокненими. Ядра ендотеліоцитів займали значну площу в клітині. Такі ядра характеризувалися нерівностям каріолеми і вираженою маргінацією хроматину. В цитоплазмі на фоні зменшення загально кількості органел досить часто зустрічалися вакуолі на місці зруйнованих внутрішньоклітинних елементів. Кількість фенестр і випинань в ендотеліоцитах помітно зменшувалася. Все це могло свідчити про зниження х активності (рис. 5). В синусо дах і капілярах печінки досить часто можна було спостерігати утворення мікротромбів. Просвіт таких капілярів був розтягнутим заповнюючими його різноманітними форменими 
Оеляди літератури, оригінальні дослідження, поеляд на проблему

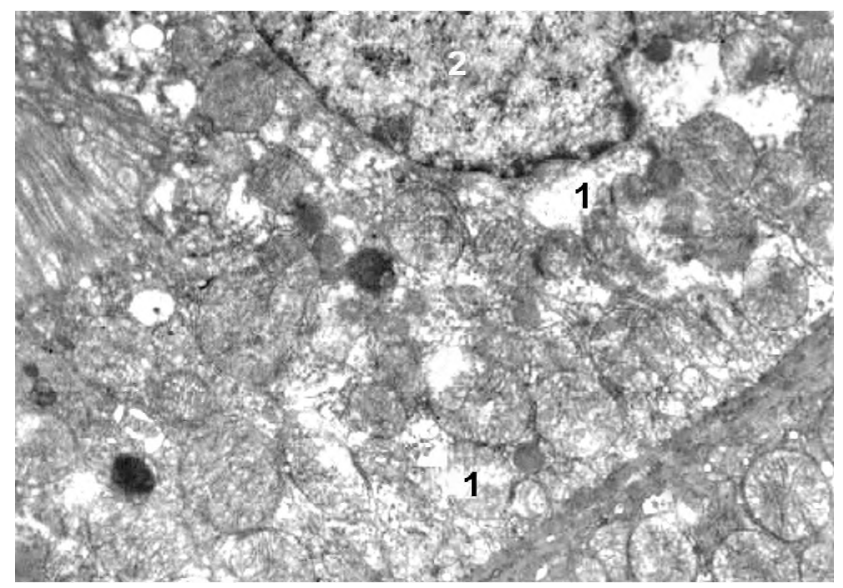

Рис. 3. Епітеліоцит ниркового канальця щура через 12 годин від початку моделювання гострого гнійного перитоніту. Фото з електронограми. Збільшення $\times 24000$. Руйнування крист мітохондрій і самих органел (1), конденсація і маргінація хроматину в ядрах (2).

елементами, між якими локалізувалися нитки фібрину. Ендотеліоцити і базальні мембрани, що формували стінки капілярів, були потоншеними по перифері. Ядра таких ендотеліальних клітин мали деформовану каріолему, а хроматин конденсувався і віддалявся від центра ядра на його периферію.

Поглиблення розладів гемодинаміки супроводжувалося прогресивним поглибленням дистро-

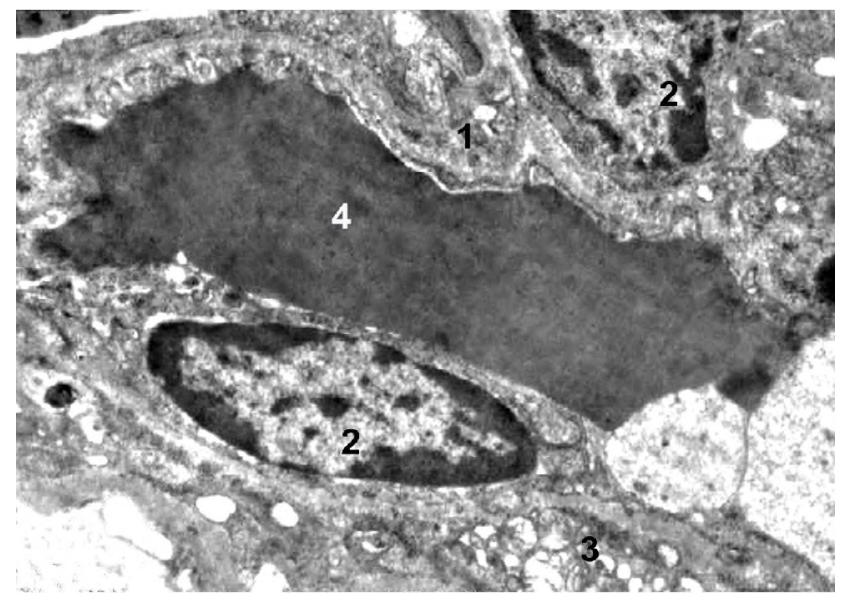

Рис. 5. Ендотеліоцити капілярів ниркового клубочка щура через 36 годин від початку моделювання гострого розлитого гнійного перитоніту. Фото з електронограми. Збільшення $\times 18000$. Базальна мембрана (1), ядра ендотеліоцитів (2), вакуолі на місці зруйнованих органел (3), гомогенна міжклітинна речовина (4).

Висновки. Виявлені в процесі дослідження морфологічні змін в судинах печінки і нирок, $\mathrm{x}$ однотипність і одночасність виникнення та характерна послідовність розвитку можуть бути наслідком безпосередніх гемодинамічних розладів, які $\epsilon$ характерними для різних стадій перитоніту, а також токсичних впливів продуктів

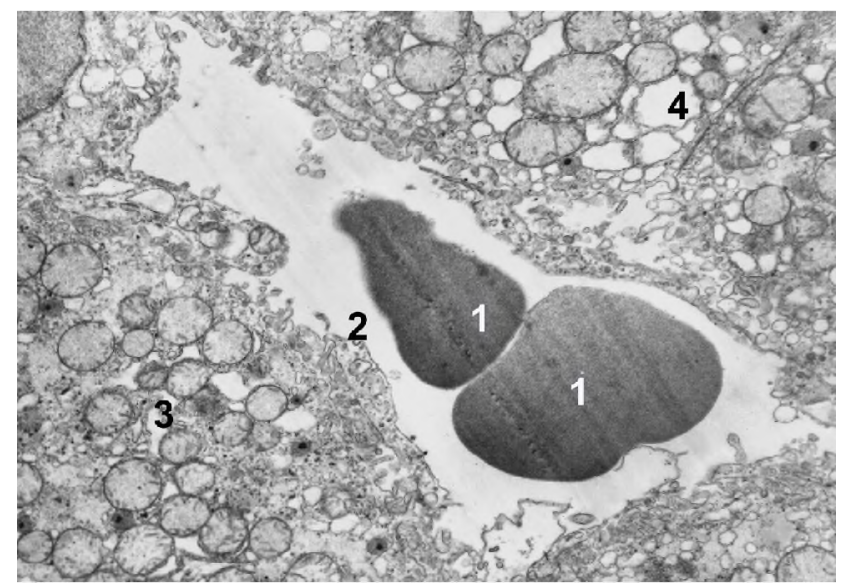

Рис. 4. Синусо дний капіляр печінки щура. Фото з електронограми. Збільшення $\times 18000$. еритроцити в просвіті синусо да (1), ендотеліоцит (2), Мітохондрі 3 частково зруйнованими кристами (3), вакуолі на місці зруйнованих органел (4).

Фічних і деструктивних процесів у паренхіматозних клітинах. Наростали явища гідропічно дистрофі, збільшувалася кількість частково і повністю зруйнованих органел з формуванням на х місці різних розмірів вакуолей як поодиноких, так і у вигляді групових скупчень. Підлягав фрагментаці як гранулярний, так і агранулярний ендоплазматичний ретикулум. Ядра епітеліоцитів виглядали переважно пікнотичними з маргінацією хроматину (рис. 6).

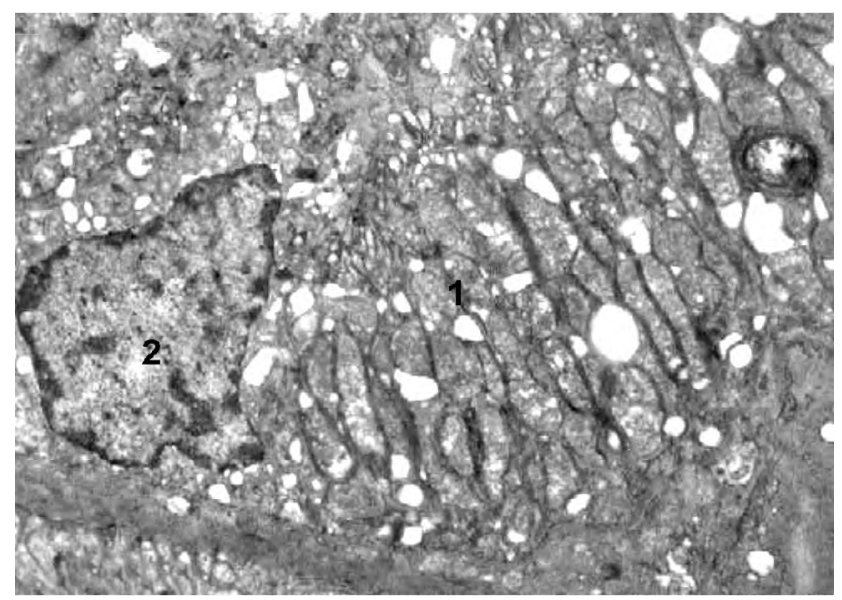

Рис. 6. Епітеліоцит канальця нирки щура через 36 годин від початку моделювання гострого розлитого гнійного перитоніту. Фото з електронограми. Збільшення $\times 36000$. Деструкція органел і вакуолізація цитоплазми (1). Пікноз ядра з маргінацією хроматину (2).

обміну, що поступають в кровоносне русло із черевно порожнини як прояв ендотоксикозу.

Перспективи подальших досліджень. Подальші дослідження дозволять обґрунтувати нові методи лікування гемодинамічних розладів, які $\epsilon$ характерними для різних стадій перитоніту, розлитого перитоніту. 
Оеляди літератури, ориаінальні дослідження, поеляд на проблему

ЛІТЕРАТУРА

1. Ерюхин И. А. Эндотоксикоз в хирургической клинике / И. А. Ерюхин, Б. В. Шашков. - СПб. : Logos, 1995. $304 \mathrm{c}$.

2. Гостищев В. К. Перитонит комплексное лечение и профилактика послеоперационных осложнений / В. К. Гостищев, А. Н. Афанасьев // Мат. II Всероссийской конф. общих хирургов. - Ростов-на-Дону, 2003. C. 10-11.

3. Абдоминальный сепсис, возможностиантибактериальной и иммунокоррегирующей терапии / Б. С. Брискин, Н. Н. Хачатрян, 3. И. Савченко [и др.] // Хирургия. 2002. - № 4. - C. 69-74.

4. The enigma of sepsis / C. Niels, R. Riedmann, RenFeng Guo, P. A. Ward // J. Clin. Invest. - 2003. - № 12. P. $460-467$.

\title{
ULTRASTRUCTURAL FEATURES OF PARENCHYMA AND VESSELS OF RAT LIVER AND KIDNEY IN DIFFERENT PERIODS OF EXPERIMENTAL DIFFUSE PERITONITIS
}

○A. V. Hantimurov

\author{
SHEI «Ternopil State Medical University by I. Ya. Horbachevsky of MPH of Ukraine»
}

SUMMARY. The results of morphological manifestations of structural adjustment of parenchyma and blood vessels of rats kidneys and liver in the dynamics of fecal peritonitis was established at the ultrastructural level.

The uniformity of the appearance and characteristic sequence of ultrastructural changes in the blood vessels of the liver and kidneys was proved, and it is the result of the immediate hemodynamic disorders specific to the various stages of peritonitis. The features of the restructuring of rats kidneys and liver vascular bed, which are caused by toxic effects of metabolic products entering the bloodstream from the abdominal cavity were found. There was marked more intensive dynamics of morphological changes of liver cells and the vascular bed than in kidney, as a result of direct reaction to the toxic effects of the affected peritoneum.

KEY WORDS: peritonitis, blood vessels, kidneys, liver. 